\section{Australian Journal of \\ Crop Science}

AJCS 15(01):164-171 (2021)

doi: 10.21475/ajcs.21.15.01.2182

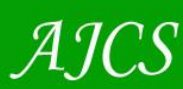

ISSN:1835-2707

\title{
Effect of post-emergence applications of imazapyr and imazapic on the growth and grain yield of AHAS-transgene soybean plants
}

\author{
Vinicius Gabriel Caneppele Pereira ${ }^{1 *}$, Leandro Paiola Albrecht ${ }^{2}$, Alfredo Junior Paiola Albrecht ${ }^{2}$, Fabio dos \\ Santos Biazoto ${ }^{3}$, Rogério Kosinski ${ }^{4}$, Aderlan Ademir Bottcher ${ }^{2}$, Mateus Dalpubel Mattiuzzi ${ }^{3}$, and Fábio \\ Henrique Krenchinski ${ }^{1}$
}

\author{
${ }^{1}$ São Paulo State University (UNESP) - School of Agricultural Sciences, Botucatu, São Paulo, Brazil \\ ${ }^{2}$ Federal University of Paraná (UFPR) - Department of Agricultural Sciences, Palotina, Paraná, Brazil \\ ${ }^{4}$ State University of Maringá (UEM) - Program of Agricultural Science, Maringá, Paraná, Brazil
}

\section{*Corresponding author: viniciuscanepp@gmail.com}

\begin{abstract}
One of the factors that limit grain yield in soybean crops is weed competition. The objective of the present work was to evaluate the agronomic performance of an AHAS-transgene soybean cultivar (BRS 397; Cultivance ${ }^{\circ}$ ) subjected to different rates of Soyvance ${ }^{\circ}$ (525 g kg-1 imazapyr, and $175 \mathrm{~g} \mathrm{~kg}^{-1}$ imazapic). Two field experiments were conducted in the 2015-2016 crop season in two sites with different soil and weather characteristics located in the state of Paraná, Brazil. A completely randomized block design was used, with 11 treatments consisted of different rates of Soyvance ${ }^{\star}$. Phytotoxicity, chlorophyll index, first pod height, plant height, number of pods per plant, 100-seed weight, and grain yield were evaluated. The use of high rates of the herbicide decreased the final height and grain yield of soybean plants in approximately $25 \%$ in both locations, but did not affect their 100 -seed weight and chlorophyll index. The use of rates of the commercial product higher than that recommended by the manufacturer $\left(100 \mathrm{~g} \mathrm{ha}^{-1}\right) \mathrm{may}$ affect the agronomic performance of AHAS-transgene soybean plants.
\end{abstract}

Keywords: Imidazolinones, selectivity, ALS inhibitors.

\section{Introduction}

The world production of soybean (Glycine max L. Merril) is increasing due to the many crop protection technologies available for this species, which allow the application of herbicides in post-emergence by making them selective to the crop and enable a production that meets the global demand. A not appropriate weed management for soybean crops can result in significant losses. Thus, technologies that allow post-emergence application of selective herbicides is an important tool for farmers.

Brazilian soybean producers have shown good acceptance of transgenic technologies for this crop; soybeans crops covered an area of approximately 35 million hectares in the $2014 / 2015$ crop season, and $93.5 \%$ of this total area was sown with genetically modified soybean seeds (Conab, 2016; Céleres, 2015). The main transgenic technology that has been adopted is Roundup Ready ${ }^{\circ}(R R)$, which enables postemergence applications of glyphosate. However, the intense use of this herbicide has significantly increased cases of resistance to this molecule. Currently, 307 cases of resistant species to 5-enolpyruvylshikimate-3-phosphate synthase (EPSPs) inhibitors have been reported all over the world, and eight of these species have been reported in Brazil (Heap, 2019).

The AHAS transgene (Cultivance ${ }^{\circ}$ technology) was developed to provide weed control options and enable rotation of herbicides of different modes of action, thus mitigating the selection of resistant weed biotypes. Soybean plants with the Cultivance ${ }^{\circ}$ technology tolerate post-emergence applications of imidazolinone-based herbicides, which are acetolactate synthase (ALS) inhibitors (Cib, 2016). ALSinhibiting herbicides account for approximately $30 \%$ of all cases of weed resistance reported worldwide. There are already 19 confirmed cases of ALS resistance in Brazil (Heap, 2019); however, most reports of resistance refer to sulfonylureas. Thus, the use imidazolinone herbicides is an alternative for the prevention biotype resistance.

Soyvance (BASF, Ludwigshafen, Germany) is an herbicide consisted of imazapyr (525 $\mathrm{g} \mathrm{kg}^{-1}$ ) and imazapic (175 g kg and is approved for post-emergence application on Cultivance soybean crops in Brazil. In the state of Paraná, this product is approved for the control of weed species, including Amaranthus viridis L., Bidens pilosa L., Brachiaria plantaginea Hitchc., Commelina benghalensis L., Digitaria horizontalis Willd, and Ipomoea grandifolia (Dammer) O'Donell (Paraná, 2016). However, some cases of resistance to ALS inhibitors have already been reported, including resistance to the chemical group of imidazolinones, for example, $B$. pilosa resistance to imazaquin and imazethapyr (Heap, 2019)

The use of imidazolinone-resistant soybean cultivars is a new tool for weed control in soybean crops; it enables rotation of herbicides of different modes of action by rotating 
transgenic cultivars in the production system. Thereby, problems due to selection of herbicide-resistant weed biotypes (as is the case of glyphosate) will be avoided, especially in integrated weed management. The use of high rates of herbicide is not recommended because it can cause a great selection pressure on weeds for resistant biotypes, decreasing the longevity of the technology. Moreover, information on the tolerance level of the technology in the field are important.

The objective of this work was to evaluate the tolerance of imidazolinone-resistant plants to post-emergence application of different rates of Soyvance $\left(525 \mathrm{~g} \mathrm{~kg}^{-1}\right.$ imazapyr, and $175 \mathrm{~g} \mathrm{~kg}^{-1}$ imazapic) on the growth and grain yield of an AHAS-transgene soybean cultivar (BRS 397; Cultivance ${ }^{\circledast}$ ).

\section{Results and Discussion}

Chlorophyll index and 100-seed weight of AHAS-transgene soybean plants after application of imazapyr + imazapic

No significant differences were found for chlorophyll index in the two areas evaluated in the present work (Table 1 and Table 2). It may be due to the evaluation time, which was at 54 days after application (DAA) of the herbicide, during the $\mathrm{R} 1$ reproductive stage. This shows that the plants had good recovery, overcoming the injuries caused by the herbicide product, whose symptoms start to decrease at 28 DAA. No significant effect was found for 100-seed weight in the two areas (Table 1), showing that this variable was not significantly affected by the increase in herbicide rates, despite presenting a slight decrease.

\section{Phytotoxicity of imazapyr + imazapic in AHAS-transgene soybean plants}

In Palotina, soybean injury was found at 7, 14, 21, and 28 DAA (Fig. 1) with the use of the lowest rates of the herbicide product $-200 \mathrm{~g} \mathrm{ha}^{-1}$ at $7 \mathrm{DAA}$, and $150 \mathrm{~g} \mathrm{ha}^{-1}$ at the other evaluation times. The soybean injury increased as the herbicide product rate was increased up to 21 DAA. The symptoms of herbicide phytotoxicity decreased after 28 DAA, showing a possible recovery of plants from the injuries after application of high rates of the herbicide. In Brasilândia do Sul, injury symptoms were found at 21 DAA; however, all percentages remained lower than $11 \%$, and the differences were not significant by the F test $(p \leq 0.05)$ (Table 2$)$.

Phytotoxicity symptoms in imidazolinone-resistant soybean plants increased up to 21 DAA, with a recovery of the plants after 28 DAA. Similar results were found for glyphosatetolerant soybean plants that presented damages to the plant photosynthetic apparatus up to 34 DAA of a high rate of glyphosate (Zobiole et al., 2010a), showing the recover ability of plants from injuries caused by high rates of herbicides (Reddy et al., 2004). Moreover, Merotto et al. (2000) evaluated the tolerance of soybean cultivars to metsulfuron-methyl (sulfonylurea) and found phytotoxicity in cultivars caused by the application of high rates of the herbicide.

The phytotoxicity was lower at 28 DAA; the plots subjected to rates of up to $250 \mathrm{~g} \mathrm{ha}^{-1}$ of the herbicide product showed less than $10 \%$ of visual injuries. However, at 28 DAA, the plants treated with herbicide rates higher than $450 \mathrm{~g} \mathrm{ha}^{-1}$ showed more than $40 \%$ phytotoxicity symptoms.

\section{First pod height and plant height after herbicide application}

The first pod height decreased as the product rate was increased (Fig. 2); similar result was found for final plant height. The increase in imazapyr + imazapic rates resulted in a small decrease in first pod height, which directly affects the efficiency of mechanical harvesting operations in soybean crops (Nepomuceno, 2007). According to Queiroz et al. (1981), soybean plants must have first pod height of at least $13 \mathrm{~cm}$ to avoid losses during mechanical harvesting. However, the results of the present study showed that the herbicide rates that caused less or no injury to the plants caused a decrease in first pod height. Therefore, even with absence of chlorosis, the high rates of herbicide used affected the internodal distance at the first pod development.

In Palotina, even the highest rates of imazapyr + imazapic did not result in first pod height below $13 \mathrm{~cm}$ (Table 1). However, the data of Brasilândia do Sul showed that the application of herbicide product rates above $300 \mathrm{~g} \mathrm{ha}^{-1}$ resulted in a first pod height of $13 \mathrm{~cm}$ or less, which may result in losses during mechanical harvesting. This effect was aggravated by the rainfall distribution in Brasilândia do Sul and by the soil field capacity, since medium-textured Ultisols are less favourable for crops than clayey Ultisols (IAC, 2016) because of their lower water retention and availability to plant roots, leading to a stress (Morando, 2014), which may aggravate injury symptoms caused by herbicides.

In both locations, the final plant height decreased as the herbicide rates was increased (Fig. 3). In Palotina, the plants showed greater tolerance, probably due the different soil type, mainly related to the water retention capacity. Albrecht et al. (2014) found the same effect for the application of glyphosate to Roundup Ready ${ }^{\circledR}$ soybeans (RR soybean), and a similar result when glyphosate was applied during the reproductive stage of the RR soybean plants. Krausz and Young (2001) found a decrease in the height of glyphosate-tolerant soybean plants subjected to application of imazethapyr.

The injuries in the soybean plants over the days after the herbicide application hindered the plant growth and decreased the internode length and the final plant height, differing from plants without herbicide application. Despite the tolerance to post-emergence application of imazapyr + imazapic, the development of the plants was affected by the highest herbicide rates used, which probably decreased grain yield.

\section{Number of pods per plant and grain yield of AHAS- transgene soybean plants after imazapyr + imazapic application}

The number of pods per plant found in Palotina presented no significant difference by the F test $(p \leq 0.05)$ (Table 1$)$. In Brasilândia do Sul, the pod number per plant was within the normal limits when applied the recommended rate of the herbicide product (100 $\mathrm{g} \mathrm{ha}^{-1}$ ) (Fig. 4). The final number of pods per plant in Brasilândia do Sul decreased as the herbicide rate was increased, presenting decreases of approximately $13 \%$ for the herbicide product rate of $275 \mathrm{~g}$ $\mathrm{ha}^{-1}$, and $22 \%$ for the highest rate (500 $\mathrm{g} \mathrm{ha}^{-1}$ ). According to Oliveira Neto et al. (2009), high rates and mixtures of herbicides can cause injury to crops, reducing the number of pods per plant and, consequently, decreasing the grain yield. 
Table 1. Analysis of variance and $F$ test for number of pods per plant, first pod height, plant height, seed weight, chlorophyll index ( $a$, $b$, and total), phytotoxicity, and grain yield of AHAS-transgene soybean plants grown in Palotina, PR, Brazil, after application of different rates of imazapyr + imazapic.

\begin{tabular}{|c|c|c|c|c|c|c|}
\hline \multicolumn{7}{|c|}{ Mean Squares } \\
\hline Factor & $\begin{array}{c}\text { Number of pods } \\
\text { per plant }\end{array}$ & First pod height & Plant height & Seed weight & $\begin{array}{l}\text { Chlorophyll index } \\
a\end{array}$ & $b$ \\
\hline Rate & $13.82^{\mathrm{ns}}$ & $64.43^{\text {ns }}$ & $364.48 * *$ & $0.29^{\text {ns }}$ & $0.55^{\mathrm{ns}}$ & $0.75^{\mathrm{ns}}$ \\
\hline Error & 20.14 & 33.86 & 19.07 & 0.72 & 3.53 & 0.70 \\
\hline CV (\%) & 10.95 & 31.24 & 4.70 & 5.18 & 5.14 & 6.66 \\
\hline Mean & 40.97 & 18.63 & 92.91 & 16.34 & 36.60 & 12.55 \\
\hline \multicolumn{7}{|c|}{ Mean Squares } \\
\hline \multirow{2}{*}{ Factor } & \multirow{2}{*}{$\mathrm{TC}$} & \multicolumn{4}{|l|}{ Phytotoxicity } & \multirow{2}{*}{ Grain yield } \\
\hline & & 7 DAA & 14 DAA & $21 \mathrm{DAA}$ & $28 \mathrm{DAA}$ & \\
\hline Rate & $2.20^{\mathrm{ns}}$ & $338.30 * *$ & $1530.60 * *$ & $1842.06 * *$ & $1439.09 * *$ & $433342.06^{* *}$ \\
\hline Error & 6.33 & 4.11 & 15.77 & 30.73 & 10.43 & 115760.74 \\
\hline CV (\%) & 5.12 & 23.66 & 20.44 & 25.89 & 17.90 & 9.59 \\
\hline Mean & 49.15 & 8.57 & 19.43 & 21.41 & 18.04 & 3548.05 \\
\hline
\end{tabular}

$\mathrm{CV}=$ coefficient of variation; DAA $=$ days after application of the herbicide; $\mathrm{TC}=$ total chlorophyll; ${ }^{* *}$ significant at $1 \%$ probability, ${ }^{*}$ significant at $5 \%$ probability, and ns $=$ not significant by the $\mathrm{F}$ test.

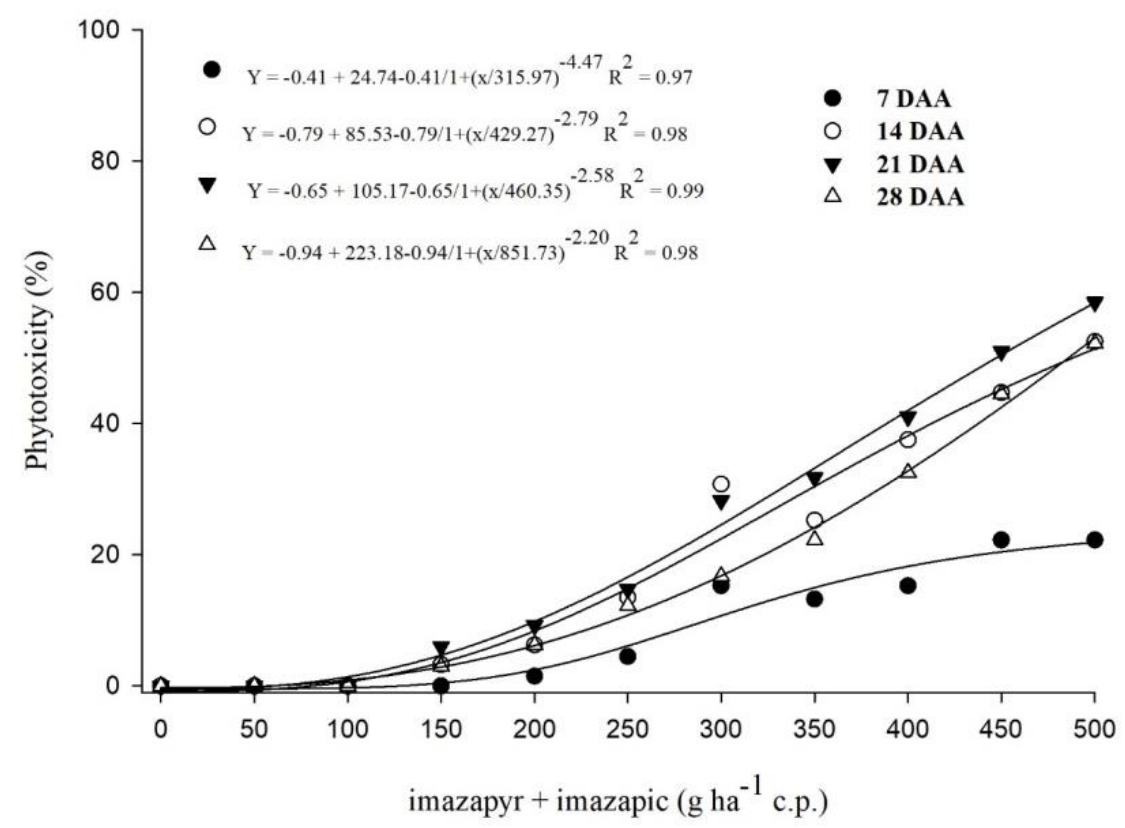

Fig 1. Phytotoxicity at $7,14,21$, and 28 days after application (DAA) of herbicide (525 g kg-1 imazapyr and $175 \mathrm{~g} \mathrm{~kg}^{-1}$ imazapic rate) to AHAS-transgene soybean plants grown in Palotina, PR, Brazil, in the 2015-2016 crop season. Data fitted to a sigmoidal regression model.

Table 2. Analysis of variance and $F$ test for number of pods per plant, first pod height, plant height, seed weight, chlorophyll index ( $a$, $b$, and total), phytotoxicity, and grain yield of AHAS-transgene soybean plants grown in Brasilândia do Sul, PR, Brazil, after application of different rates of imazapyr + imazapic.

\begin{tabular}{|c|c|c|c|c|c|c|}
\hline \multicolumn{7}{|c|}{ Medium Squares } \\
\hline Factor & $\begin{array}{l}\text { Number of pods per } \\
\text { plant }\end{array}$ & First pod height & Plant height & Seed weight & $\begin{array}{l}\text { Chlorophyll index } \\
a\end{array}$ & $b$ \\
\hline Rate (R) & $46.90^{* *}$ & $19.90 * *$ & $173.96^{* *}$ & $0.93^{\mathrm{ns}}$ & $14.23^{\mathrm{ns}}$ & $1.39^{\mathrm{ns}}$ \\
\hline Error & 11.73 & 3.25 & 26.01 & 1.26 & 5.95 & 1.82 \\
\hline CV (\%) & 9.40 & 12.05 & 6.10 & 6.97 & 7.44 & 12.33 \\
\hline Mean & 36.44 & 14.97 & 83.67 & 16.10 & 32.81 & 10.93 \\
\hline \multicolumn{7}{|c|}{ Medium Squares } \\
\hline \multirow{2}{*}{ Factor } & \multirow{2}{*}{ Chl. Total } & \multicolumn{4}{|l|}{ Phytotoxicity } & \multirow{2}{*}{ Grain yield } \\
\hline & & $7 \mathrm{DAA}$ & 14 DAA & $21 \mathrm{DAA}$ & 28 DAA & \\
\hline Rate (R) & $20.06^{\mathrm{ns}}$ & $315.22^{\text {ns }}$ & $210.76^{\mathrm{ns}}$ & $21.02^{\mathrm{ns}}$ & $3.00^{\mathrm{ns}}$ & $779027.97 * *$ \\
\hline Error & 10.58 & 373.73 & 255.78 & 32.22 & 2.97 & 149607.68 \\
\hline CV (\%) & 7.44 & 81.01 & 96.38 & 96.44 & 161.29 & 12.21 \\
\hline Mean & 43.74 & 23.86 & 15.59 & 5.89 & 1.07 & 3169.09 \\
\hline
\end{tabular}




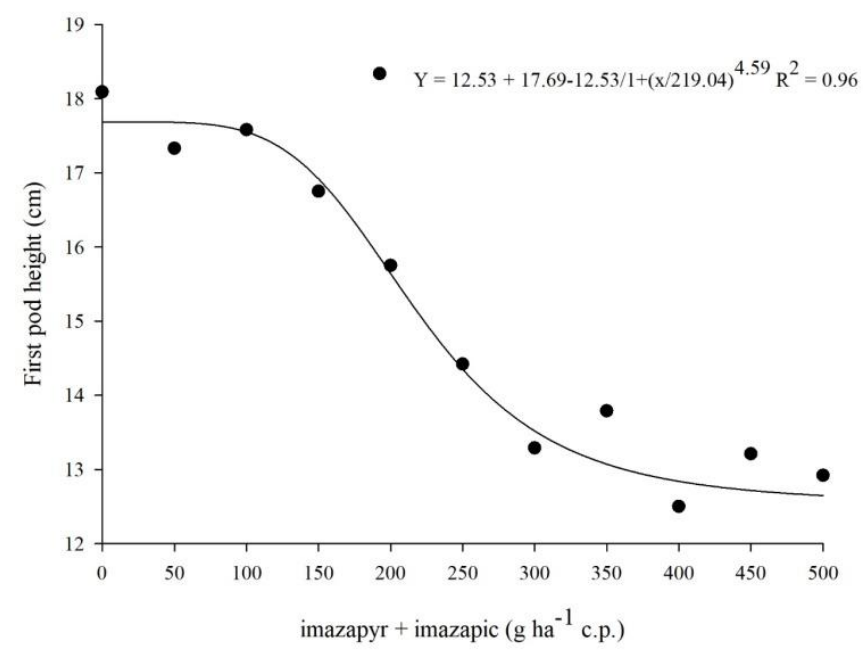

Fig 2. First pod height $(\mathrm{cm})$ after application of herbicide ( $525 \mathrm{~g} \mathrm{~kg}^{-1}$ imazapyr and $175 \mathrm{~g} \mathrm{~kg}^{-1}$ imazapic rate) to AHAS-transgene soybean plants grown in Brasilândia do Sul, PR, Brazil, in the 2015-2016 crop season. Data fitted to a sigmoidal regression model.

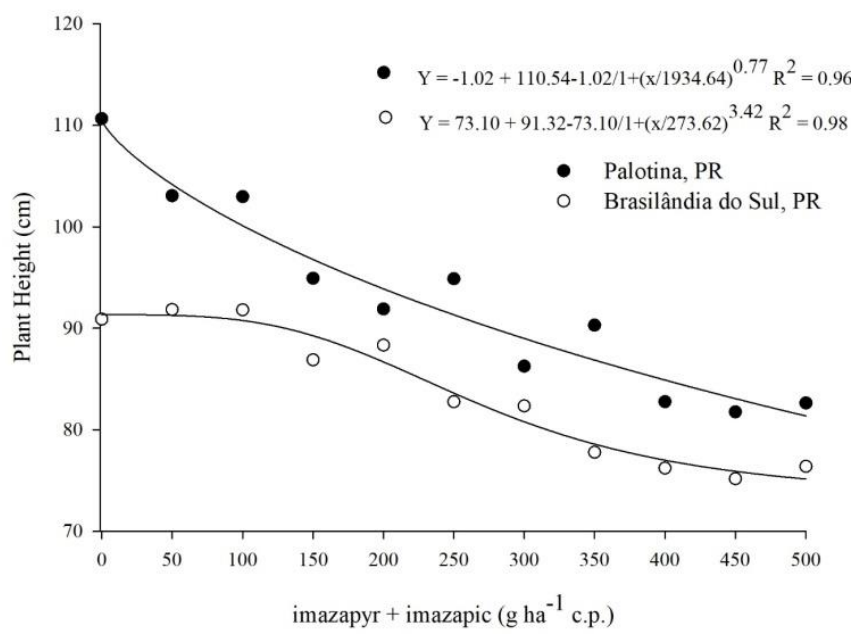

Fig 3. Plant height $(\mathrm{cm})$ after application of herbicide ( $525 \mathrm{~g} \mathrm{~kg}^{-1}$ imazapyr and $175 \mathrm{~g} \mathrm{~kg}^{-1}$ imazapic rate) to AHAS-transgene soybean plants grown in Palotina and in Brasilândia do Sul, PR, Brazil, in the 2015-2016 crop season. Data fitted to a sigmoidal regression model.

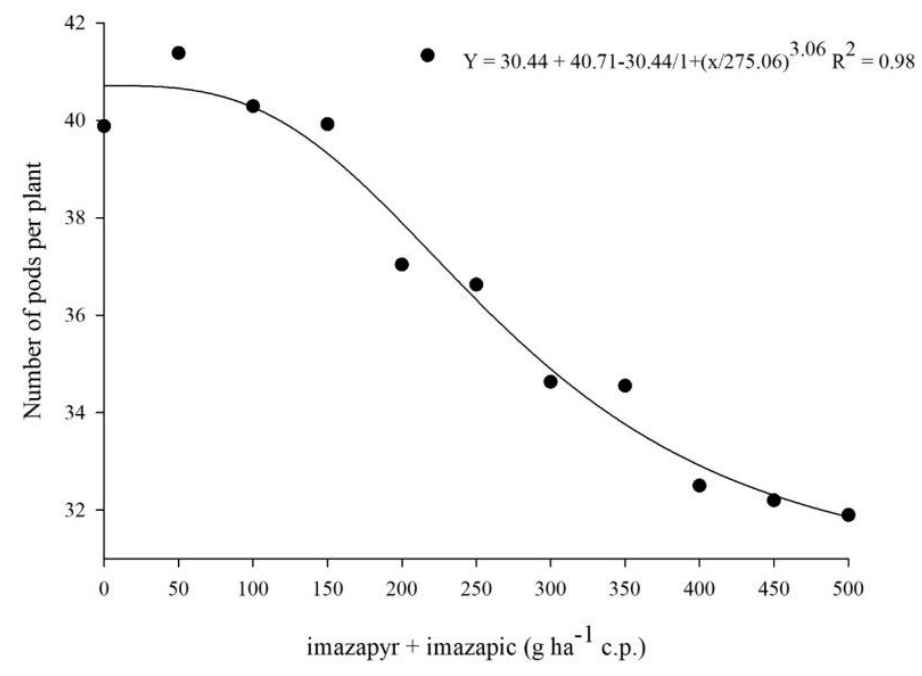

Fig 4. Number of pods per plant after application of herbicide ( $525 \mathrm{~g} \mathrm{~kg}^{-1}$ imazapyr and $175 \mathrm{~g} \mathrm{~kg}^{-1}$ imazapic rate) to AHAS-transgene soybean plants grown in Brasilândia do Sul, PR, Brazil, in the 2015-2016 crop season. Data fitted to a sigmoidal regression model. 


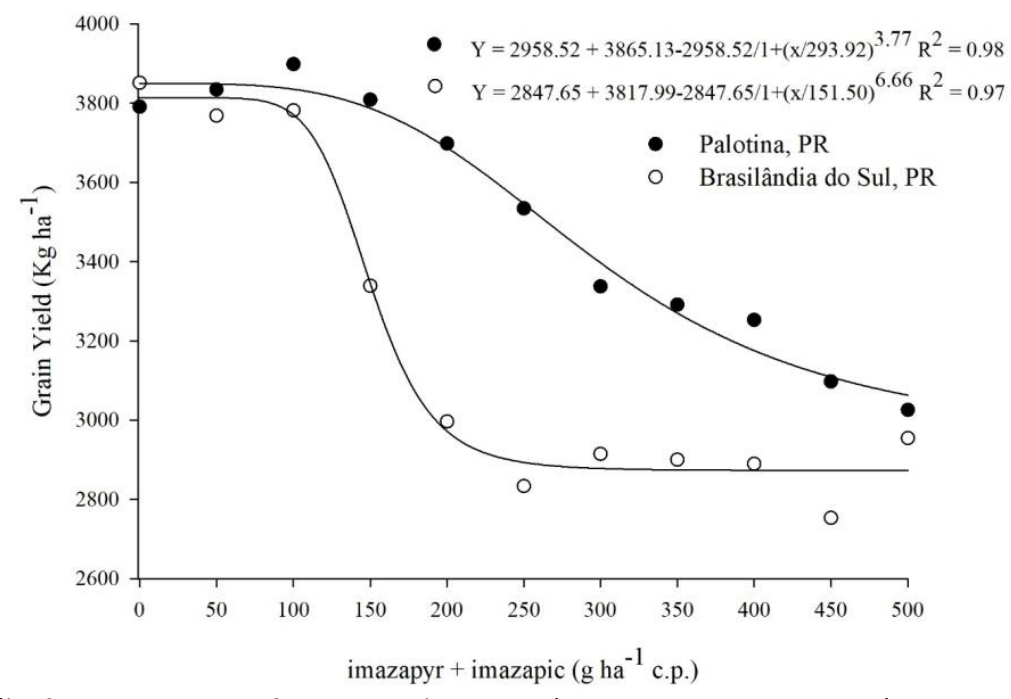

Fig 5. Grain yield ( $\left.\mathrm{kg} \mathrm{ha}^{-1}\right)$ after application of herbicide (525 g kg-1 imazapyr and $175 \mathrm{~g} \mathrm{~kg}^{-1}$ imazapic rate) to AHAS-transgene soybean plants grown in Palotina and in Brasilândia do Sul, PR, Brazil, in the 2015-2016 crop season. Data fitted to a sigmoidal regression model.

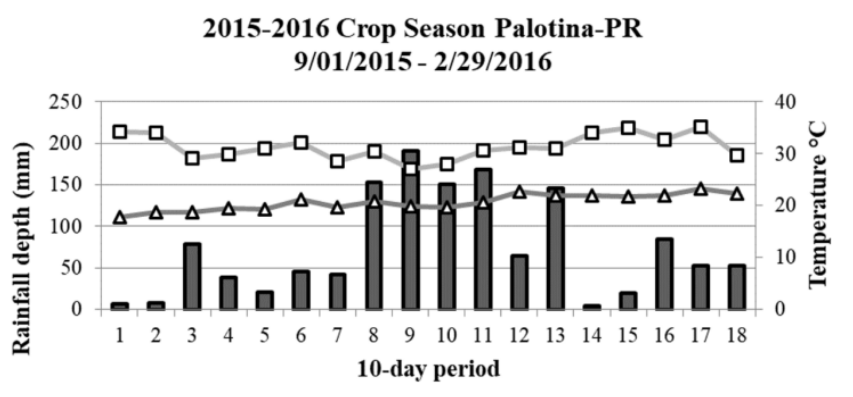

Fig 6. Average rainfall depth and air temperature in the 2015-2016 crop season, in Palotina, PR, Brazil.

2015-2016 Crop Season Brasilândia do Sul, PR

9/01/2015 - 2/29/2016

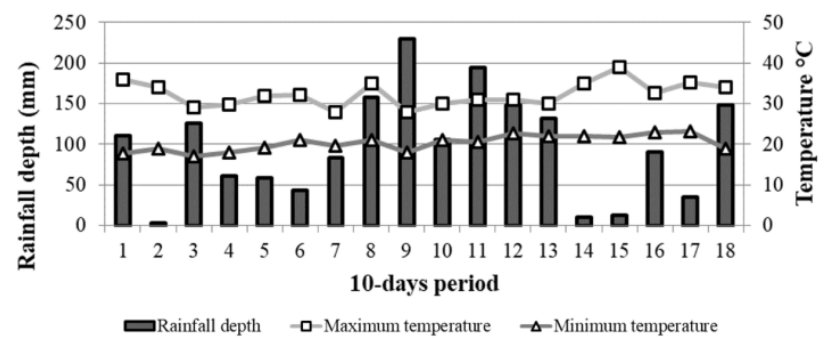

Fig 7. Average rainfall depth and air temperature in the 2015-2016 crop season, in Brasilândia do Sul, PR, Brazil.

Some studies have reported negative effects of increasing herbicide rates on number of pods per plant. Albrecht et al. (2011) found this result with application of increasing rates of glyphosate to RR soybean cultivars, regardless the stage of the plants at the herbicide application (vegetative and reproductive). Zadinello et al. (2012) found similar effect when applying glyphosate at the beginning of the reproductive stage.

Corrêa and Alves (2009) evaluated the application of a mixture of glyphosate and imazethapyr to transgenic soybean plants and found that the application of an imidazolinone had no effect on number of pods per plant. The decreases in number of pods per plant is connected to flower abortion during the reproductive period, which may be due to problems in the photosynthetic system or in the water use efficiency (Zobiole et al., 2010b). Martendal (2016) found a decrease in number of siliques in canola hybrids when using different rates of an herbicide consisted of imazethapyr ( $\left.75 \mathrm{~g} \mathrm{~L}^{-1}\right)$ and imazapic $\left(25 \mathrm{~g} \mathrm{~L}^{-1}\right)$ (Only ${ }^{\oplus}$; BASF, Ludwigshafen, Germany). Variables that affect grain yield, such as number of pods per plant, plant height, and chlorophyll indexes, may be decreased as the rate of this herbicide is increased (Albrecht et al., 2014).

The grain yield of the imidazolinone-resistant soybean plants was affected by the increase of herbicide rates because of injuries in the plants during their vegetative stage, in both locations. This effect was more pronounced in Brasilândia do Sul, where the grain yield was, in general, lower than that 
found in Palotina (Fig. 5). The grain yield of the imidazolinone-resistant soybean plants decreased approximately $13 \%$ when the herbicide product was applied at a rate of $150 \mathrm{~g} \mathrm{ha}^{-1}$; however, there was a relative decrease of $25 \%$ when applying rates 4.5 - to 5 -fold higher than the recommended one. The use of high rates of herbicides is not recommended; it can result in greater selection pressure for resistant weed biotypes, thereby, decreasing the longevity of the technology.

Albrecht et al. (2014) found a decrease in grain yield of RR soybean plants grown in different sites and crop seasons when applying increasing rates of glyphosate. This effect was also found for application of glyphosate at the beginning of the reproductive stage, even to glyphosate-resistant soybean plants (Albrecht et al., 2011; Zadinello et al., 2012). According to Albrecht et al. (2012), combinations of herbicides may increase plant injury; they found that the use of a combination of glyphosate and chlorimuron-ethyl resulted in more significant decreases in grain yield than the use of glyphosate alone.

The imidazolinone-resistant soybean plants grown in Palotina showed higher tolerance to high rates of the herbicide product (Fig. 5). The technology proved to be efficient for tolerance to post-emergence applications of imazapyr + imazapic. The highest rates used decreased grain yields in up to $24 \%$. However, under the climatic conditions in the 2015-2016 crop season and the soil conditions, the tolerance of the imidazolinone-resistant soybean plants to the herbicide product rates of up to $250 \mathrm{~g} \mathrm{ha}^{-1}$ applied in post-emergence was found in the AHAS-transgene production system. However, the use of the recommended rate is necessary to preserve the technology, reducing the selection pressure for resistant weeds.

The significant decrease in grain yield due to the use of the highest rates of the herbicide product is related to the resulting injuries in the plants at the vegetative stage. In Palotina, the phytotoxicity symptoms increased up to 21 DAA; however, the use of herbicide product rates greater than $450 \mathrm{~g} \mathrm{ha}^{-1}$ resulted in more than $40 \%$ of injuries at 28 DAA. Therefore, there was a shorter time for planting, which affected the productive parameters and agronomic performance of the plants, since the grain yield is a result from other plant attributes (Carvalho et al., 2002).

\section{Materials and Methods}

\section{Plant material}

The BRS 397 soybean cultivar was chosen for the present study. It is in the maturity group 6.2 , has indeterminate growth habit, purple flowers, gray pubescence, and lightbrown hilum, and its grains present average protein and oil contents of $38.2 \%$ and $23.0 \%$, respectively. These plants can reach heights of 80 to $100 \mathrm{~cm}$, and 100 -seed weight of $15 \mathrm{~g}$ (BASF, 2016).

The cultural practices used for this cultivar in the present study followed the guidelines of the Embrapa (2008). The seeds were sowed in both locations on 1 October 2015, at rate of 310,000 seeds ha-1, with spacing of $0.45 \mathrm{~m}$ between rows. The plots consisted of six 5-meter rows, with an evaluation area of $3.6 \mathrm{~m}^{2}$. The plots were kept free from weeds through manual weeding, as described by Embrapa (2008).

\section{Field Experiments}

Two field experiments with soybean crops under no-till system were conducted in different environments in western state of Paraná, Brazil, during the 2015-2016 crop season: one in Palotina (Area 1) $\left(24^{\circ} 20^{\prime} 49^{\prime \prime} \mathrm{S}, 53^{\circ} 51^{\prime} 32^{\prime \prime} \mathrm{W}\right.$, and altitude of $346 \mathrm{~m}$ ) and other in Brasilândia do Sul (Area 2) (2405"13"S, 5329"32"W, and altitude of $378 \mathrm{~m}$ ).

The soil of the Area 1 was classified as Typic Hapludox (Latossolo Vermelho eutroferrico; Embrapa, 2006) of clayey texture ( $63.75 \%$ clay, $17.50 \%$ silt, and $18.75 \%$ sand), whose $0-20 \mathrm{~cm}$ layer presented $\mathrm{pH}\left(\mathrm{CaCl}_{2}\right)$ of $4.5,13.42 \mathrm{~g} \mathrm{dm}^{-3}$ of organic matter, $59.09 \mathrm{mg} \mathrm{dm}^{-3}$ of $\mathrm{P}$, and $0.27,1.42$, and 0.00 $\mathrm{cmol}_{\mathrm{c}} \mathrm{dm}^{-3}$ of $\mathrm{K}^{+}, \mathrm{Ca}^{2+}$, and $\mathrm{Al}^{3+}$, respectively. The soil of the Area 2 was classified as Typic Paleudalf (Argissolo Vermelho Amarelo distrofico; Embrapa, 2006) of medium texture (30\% clay, $15 \%$ silt, and $55 \%$ sand), whose $0-20 \mathrm{~cm}$ layer presented $\mathrm{pH}\left(\mathrm{CaCl}_{2}\right)$ of $5.3,14.45 \mathrm{~g} \mathrm{dm}^{-3}$ of organic matter, $30.44 \mathrm{mg} \mathrm{dm}^{-3}$ of $\mathrm{P}$, and $0.30,2.67$, and $0.00 \mathrm{cmol}_{\mathrm{c}} \mathrm{dm}^{-3}$ of $\mathrm{K}^{+}$, $\mathrm{Ca}^{2+}$, and $\mathrm{Al}^{3+}$, respectively.

The climate of the region encompassing both locations is Cfa (humid temperate with hot summers), according to the Köppen classification. The rainfall depth and air temperature data were monitored daily during the experiments in Palotina (Fig. 6) and Brasilândia do Sul (Fig. 6).

These sites were selected because they present different edaphoclimatic characteristics, thus enabling the evaluation of responses of these soybean plants under different conditions.

\section{Experimental design and herbicide application}

The experiments were conducted in a completely randomized block design with four replications. The treatments consisted of 11 rates $(0,50,100,150,200,250$, $300,350,400,450$, and $500 \mathrm{~g} \mathrm{ha}^{-1}$ ) of the herbicide Soyvance (BASF, Ludwigshafen, Germany), whose active ingredients are imazapyr $\left(525 \mathrm{~g} \mathrm{~kg}^{-1}\right)$ and imazapic (175 g kg$\left.{ }^{1}\right)$. The product rate recommended by the manufacturer is $100 \mathrm{~g} \mathrm{ha}^{-1}$.

The treatments were applied when $50 \%$ of the plants had four expanded leaves $\left(\mathrm{V}_{4}\right.$ stage) using a $\mathrm{CO}_{2}$-pressurized backpack sprayer under constant pressure (29 psi), with flow rate of $0.65 \mathrm{~L} \mathrm{~min}{ }^{-1}$. The sprayer had a spray boom containing six extended range flat spray nozzles (XR 11002; Teejet $^{\circledR}$, Wheaton, USA), positioned at $50 \mathrm{~cm}$ height from the target, moving at a speed of $1 \mathrm{~m} \mathrm{~s}^{-1}$, resulting in a $50-\mathrm{cm}$ wide coverage per nozzle and in an application volume corresponding to $200 \mathrm{~L} \mathrm{ha}^{-1}$.

In the Area 1, the treatments were applied on 30 October 2015 , under average temperature, wind speed, and relative air humidity of $25.6{ }^{\circ} \mathrm{C}, 5 \mathrm{~km} \mathrm{~h}^{-1}$, and $63.7 \%$, respectively. In Area 2, the treatments were applied on 6 November 2015, under average temperature, wind speed, and relative air humidity of $27^{\circ} \mathrm{C}, 6 \mathrm{~km} \mathrm{~h}^{-1}$, and $62 \%$, respectively. The plants were manually harvested when they reached full maturity: 95\% mature pods, based on their colour (R8 stage).

\section{Data collection}

The variables evaluated were plant height, number of pods per plant, chlorophyll index ( $a, b$, and total), grain yield, and 100 -seed weight. Phytotoxicity was evaluated visually by quantifying interveinal chlorosis and necrosis on the plants of each plot at 7, 14, 21, and 28 days after application (DAA) 
of the herbicide product, based on injury symptoms, using a scale of grades from 0 (absence of injuries) to 100 (plant death) (SBCPD, 1995).

Ten plants were randomly selected in the evaluation area of each plot and evaluated for first pod height and final height. First pod height $(\mathrm{cm})$ was measured at full maturity of the plants in both locations. Chlorophyll index was measured at 54 DAA (R1 reproductive stage), using a chlorophyll meter (ClorofiLOG; Falker, Porto Alegre, Brazil); the result was expressed as average of five plants. The number of pods per plant was evaluated at the $\mathrm{R} 8$ reproductive stage. The $100-$ seed weight was determined by counting and weighing 8 subsamples of 100 seeds, and grain yield was estimated in $\mathrm{kg}$ $\mathrm{ha}^{-1}$; the grain moisture content was adjusted to $13 \%$ for these two variables.

\section{Statistical analyses}

The data of all treatments were subjected to analysis of variance (ANOVA) at $5 \%$ significance level by the $F$ test, calculating the $p$-value, and to regression analysis at $5 \%$ probability, according to Pimentel-Gomes and Garcia (2002), using the Sisvar program(Ferreira, 2011). The sites were evaluated separately. Subsequently, the data were fit to non-linear regression models, according to Seefeld et al. (1995), using the SigmaPlot program, according to Equation 1.

$y=P \operatorname{mí} n+\frac{a}{\left[1+\left(\frac{x}{b}\right)^{c}\right]}$

Where:

$y=$ response of the variable;

$x=$ herbicide product rate $\left(\mathrm{kg} \mathrm{ha}^{-1}\right)$

Pmín = lower limit;

$a=$ amplitude between the lower and upper value of the variable;

$b=$ herbicide rate which provides $50 \%$ response of the variable;

$c=$ slope.

\section{Conclusion}

The imidazolinone-resistant soybean plants showed tolerance to imazapyr + imazapic herbicide in both locations evaluated in the present study. The 2015-2016 crop season had regular, well-distributed rainfall, which favoured the crop development and the recovery of plants from injuries caused by the herbicide. The use of high rates of the evaluated herbicide are not recommended, especially under irregular and infrequent rainfall conditions. Further studies about this soybean technology over longer periods and under different soil characteristics are needed.

The use of AHAS-transgene soybean plants is an alternative for the rotation of mechanisms of action of herbicides, enabling a preventive control of selection of weeds resistant to herbicides.

\section{Acknowledgements}

The authors thank the Federal University of Paraná for the support during the development of this study, and the company BASF for collaborating to this research.

\section{References}

Albrecht AJP, Albrecht LP, Krenchinski FH, Placido HF, Lorenzetti JB, Victoria Filho R, Barroso AAM (2014) Behavior of RR soybeans subjected to different formulations and rates of glyphosate in the reproductive period. Planta Daninha. 32:851-859.

Albrecht LP, Alonso DG, Albrecht AJP, Oliveira Júnior RS, Braccini AL, Constantin J (2012) Glyphosate e associações em pós-emergência no desempenho agronômico e na qualidade das sementes de soja RR. Planta Daninha. 30:139-146.

Albrecht LP, Barbosa AP, Silva AFM, Mendes MA, MaraschiSilva LM, Albrecht AJP (2011) Desempenho da soja roundup ready sob aplicação de glyphosate em diferentes estádios. Planta Daninha. 29:585-590.

BASF. Sistema Cultivance ${ }^{-}$Available in: < http://www.agro.basf.com.br/agr/ms/apbra zil/pt_BR/content/APBrazil/solutions/cultivance/sistema>. Accessed on: 13 September 2016.

Carvalho CGP, Arias CAA, Toledo JFF, Oliveira MF, Vello NA (2002) Correlações e análise de trilha em linhagens de soja semeadas em diferentes épocas. Pesqui Agropecu Bras. 37:311-320.

Céleres (2015) informativa biotecnologia: Relatório do ano de $2015 . \quad$ Available in: <http://www.celeres.com.br/docs/biotecnologia/IB1501_ 150611.pdf>. Accessed on: 26 September 2016.

Conselho de informações sobre biotecnologia (CIB) (2016) Eventos Aprovados. Available in: < http://cib.org.br/biotecn ologia/regulamentacao/ctnbio/eventos-aprovados/bpscv127-9-cultivance> Accessed on: 28 October 2016.

Companhia nacional de abastecimento (CONAB) (2016) Acompanhamento da safra brasileira: Safra 2015/16 Décimo primeiro levantamento, 3:11-176.

Corrêa MJP, Alves PLCA (2009) Eficácia de herbicidas aplicados em pós-emergência na cultura da soja convencional e transgênica. Planta Daninha. 27:10351046.

Empresa Brasileira de Pesquisa Agropecuária (EMBRAPA) (2006) Sistema brasileiro de classificação de solos. 2. ed. Rio de Janeiro: Embrapa Solos.

Empresa Brasileira de Pesquisa Agropecuária (EMBRAPA) (2008) Tecnologia de produção de soja: região central do Brasil. 12. ed. Londrina: Embrapa Soja; Embrapa Cerrados; Embrapa Agropecuária Oeste.

Ferreira DF (2011) Sisvar: a computer statistical analysis system. Cienc Agrotec. 35: 1039-1042.

Heap I (2019) The International Survey of Herbicide Resistant Weeds. Available in: <www.weedscience.org>. Accessed on: 04 April 2019.

Instituto agronômico de Campinas (IAC) (2016) Solos do estado de São Paulo - Argissolos. Available in: <http://www.iac.sp.gov.br /solossp/pdf/Argissolos.pdf>. Accessed on: 22 October 2016.

Krausz RF,Young BG (2001) Response of double-crop glyphosate-resistant soybean (Glycine max) to broadleaf herbicides. Weed Technol. 15:300-305.

Martendal J (2016) Seletividade de herbicidas do grupo das imidazolinonas aplicados em pós-emergência na cultura da canola $\mathrm{CL}^{\circ}$. Trabalho de conclusão de curso . Curitibanos, SC. Universidade Federal de Santa Catarina - Centro de Curitibanos $28 p$. 
Merotto Jr A, Vidal RA, Fleck NG. (2000) Tolerância da cultivar de soja Coodetec 201 aos herbicidas inibidores de ALS. Planta Daninha. 18: 93-102.

Morando R, Silva AOS, Carvalho LC, Pinheiro, MPMA. (2014) Déficit hídrico: efeito sobre a cultura da soja. Journal of Agronomic Science. 3:114-129.

Nepomuceno M, Alves PLCA, Dias TCS, Pavani MCMD (2007) Períodos de interferência das plantas daninhas na cultura da soja nos sistemas de semeadura direta e convencional. Planta Daninha. 25:43-50.

Oliveira Neto MEF, Pitelli RA, Basile AG, Timossi PC (2009) Seletividade de herbicidas pós-emergentes aplicados na soja geneticamente modificada. Planta Daninha. 27:345352.

Paraná (Estado) Adapar (2016) Agrotóxicos no Paraná. Available in: <http://www.adapar.pr.gov.br/mo dules/conteudo/conteudo.php?conteudo=387>. Accessed on: 07 November 2016.

Pimentel-Gomes F, Garcia, CH (2002) Estatística aplicada a experimentos agronômicos e florestais: exposição com exemplos e orientações para uso de aplicativos. Piracicaba: FEALQ, 309p.
Queiroz EF, Neumaier N, Torres E, Pereira LAG, Bianchetti A, Terazawa F, Palhano JB, Yamashita J (1981) Recomendações técnicas para a colheita mecânica. Pages 701-710 In Miyasaka S, Medina JC ed.. A soja no Brasil. Campinas.

Reddy KN, Rimando AM, Duke ST (2004) Aminomethylphosphonic acid, a metabolite of glyphosate, causes injury in glyphosate-treated, glyphosate-resistant soybean. J Agr Food Chem. 52:5139-5143.

SBCPD - Sociedade Brasileira da Ciência das Plantas Daninhas (1995) Procedimentos para instalação, avaliação e análise de experimentos com herbicidas Londrina 42p.

Seefeld SS, Jensen JE, Fuerst EP (1995) Log-logistic analysis of herbicide rate-response relationship. Weed Technol. 9:218-227.

Zadinello R, Chaves MM, Santos RF, Bassegio D, Werncke (2012) Influência da aplicação de glifosato na produtividade da soja. Acta Iguazu. 1:1-8.

Zobiole LHS, Kremer RJ, Oliveira Júnior, RS, Constantin J (2010a) Glyphosate affects photosynthesis in first and second generation of glyphosate-resistant soybeans. Plant Soil. 336:251-265.

Zobiole LHS, Oliveira Júnior RS, Kremer RJ, Constantin J, Bonato CM, Muniz AS (2010b) Water use efficiency and photosynthesis of glyphosate-resistant soybean as affected by glyphosate. Pestic Biochem Phys. 97:182-193. 